\title{
Organisational learning, strategic rigidity and technology adoption: Implications for electric utilities and renewable energy firms
}

\author{
Arsalan Nisar ${ }^{\text {a,* }}$, Felipe Ruiz ${ }^{a}$, Miguel Palacios ${ }^{\mathrm{b}}$

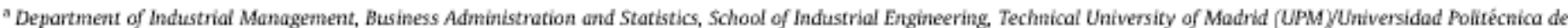 \\ Modrid Jose of José Gutiérrez Abascal, 2, 28006 Madrid, Spain \\ 'ESCP Europe d/ Arroyofresno, 128035 Madrid, Spoin
}

\begin{abstract}
A B S T R A C T
This paper examines the implications of strategic rigidness for technology adoption behaviours among electric utilities. Such behaviours lead to heterogeneity in firm performance and consequently affect the electric utility industry. The paper's central aim is to identify and describe the implications of strategic rigidness for a utility firm's decision making in adopting newer renewable energy technologies. The findings indicate that not all utility firms are keen to adopt these new technologies, as these firms have traditionally been operating efficiently with a more conventional and mature technological arrangement that has become embedded in the organisational routine. Case studies of Iberdrola S.A. and Enel S.p.A. as major electric utilities are detailed to document mergers and acquisitions and technology adoption decisions. The results indicate that technology adoption behaviours vary widely across utility firms with different organisational learning processes and core capabilities.
\end{abstract}

\section{Contents}

1. Introduction

1.1. Structure and contents

2. Rescarch framework

3. Strategic rigidity and firm performance heterogeneity: frame of reference

4. Branching, innovation and policy implications

5. Case study: Iberdrola S.A.

5.1. Mergers and acquisitions at Iberdrola S.A.

5.2. Concentrated solar power technologies: status and future prospects

5.3. Timeline for concentrated solar power technology

5.4. Core capabilities, strategic rigidity and competitive advantage

6. Case study: Enel S.p.A.

6.1. Enel green power

6.2. Mergers and acquisitions with technology adoption behaviour at Enel S.p.A

7. Energy policy, economies of scale and renewable energy technologies

8. Network effects

9. Discussion and conclusions

References

\footnotetext{
* Corresponding author. Tel./fax: + 34913363095.

E-mail address: arsalan.nisarøalumnos.upmes (A. Nisar).
}

\section{Introduction}

As electric utilities respond to market competition, climate change and the importance of increasing the share of renewables in the energy mix, there is a growing recognition of the pivotal role of technology in determining market success. As a result of 
this recognition, most utility firms have increased their adoption of advanced technologies and augmented their focus in introducing novel technologies to the market. Scholars of innovation and organisational theory posit that the fundamental question firms must address is the manner in which the firms can sustain competitive advantage. The literature in this field attempts to answer why firms within the same industry perform differently. Scholars have considered the resource-based view (RBV) to be the underlying reason for firm performance heterogeneity. The RBV proposes that firms within an industry differ in the resources and capabilities they possess and control, thereby leading to heterogeneous positions within the industry. Accordingly, each firm within a specific industry may be considered a bundle of resources and capabilities [1].

More specifically, past research [2] suggests that organisational capabilities considered within the RBV are essential for competitive advantage and are a major source of firm performance [2-4]. Moreover, dynamic capabilities encapsulate wisdom from earlier work on distinctive competence $[5,6]$, organisational routine [7], architectural knowledge [8], core competence [9], core capability and rigidity [10], combinative capability [11] and architectural competence [12]. The variation in the adoption of a technology can be attributed to the integrative capability of a firm [5]. Importantly, the competitive advantage obtained through the adoption of an innovative technology may be temporary at best. Thus, it is essential for firms to adopt technologies that are new or to adopt multiple technologies to achieve a competitive advantage that is more sustainable. In addition, technological opportunism as a firm-level capability is consistent with multiple research perspectives on organisational traits and capabilities $[3,4,13]$. Miles and Snow [4] suggest that an opportunistic firm senses technology opportunities and is proactive in capitalising on (or countering) these environmental prospects (or threats). Likewise, technologically opportunistic firms are in an enactment mode with respect to new technologies insofar as they explore several novel technologies that could threaten their organisations or be sources of opportunity $[14,15]$.

Within the electric utility industry, competitive advantage is of great importance, as it summarises the process of value creation and value capture for firms. Thus, this paper builds upon the cornerstones of the strategic management literature to analyse decisions made by these firms to achieve a sustainable firm performance. Often, the discourse on energy policy as part of the electric utility industry is based on the assumption that the focus should be on the energy system as a whole and that policy initiatives with respect to deregulation, investment and environmental impact must be considered as a part of this system, from generation to transmission and distribution and finally to consumption. This paper takes a different approach in that it conceptualises the notion of competitive advantage from a firm's point of view and addresses the role of the firm within the energy eco-system. In this paper, we study the role of strategic rigidness brought about by a firm's competitive advantage in a different technological arrangement (often mature) and its implications for the adoption of newer renewable energy (RE) technologies.

Moreover, the renewable energy sector depends on technological innovations for the sustainable production of energy, and the utility firms act as agents of change and innovation. Many of the utility firms that operate within a specific market seek to adopt these new technologies to be competitive in the marketplace. However, not all utility firms are keen to adopt these new technologies, as these firms have traditionally been operating efficiently with a more conventional form of technology that, as a result, has become embedded in the organisational routine. We propose that this reluctance or delay in adopting new technologies can be characterised as strategic rigidness, which forms as a result of a firm's core competence and core capability in a different, more conventional technology arrangement. Most utility firms have a renewable energy portfolio aimed at augmenting the adoption of $\mathrm{RE}$ technologies to increase the sustainable production of energy. This paper examines the role of a firm's capabilities in established technologies in influencing the firm's technology adoption decisions. While some utility firms have made large strides in distributing electricity from RE sources, others have postponed this practice.

This paper argues that firms' stronger capabilities in conventional technologies can become rigidities that push these firms to further exploit more mature technologies rather than investing in new innovative technologies. This paper considers this phenomenon among electric utility firms from a strategic perspective and outlines possible implications.

\subsection{Structure and contents}

This paper is structured as follows: in the first section, we discuss the research framework by emphasising the relevant literature regarding strategic rigidity, technology adoption and firm performance heterogeneity. In Sections 3 and 4, we examine barriers to RE technology by emphasising various policy implications. In Sections 5 and 6, we provide background on the electric utility industry, describe the data and document the pattern of technology adoption by examining the case studies of Iberdrola S.A. and Enel S.p.A. Finally, the last section concludes with a discussion and future research directions.

\section{Research framework}

This paper aims to understand how organisational capabilities with respect to factors such as environmental dynamism may create strategic rigidity within a firm (Table 1). In the case of a utility firm, these factors may result in the late adoption of an RE technology that is innovative and that can maintain the firm's competitive advantage in the future. The likely areas of competitive advantage may lie in the periphery of the firm's strategic vision and can easily become blurred as a result of rigidness, thus permeating the firm's decision-making process. These considerations form the basis of this paper's research framework Fig. 1.

For instance, an oil firm's decision to enter or to exit the solar industry has more far-reaching consequences than another firm's decision to extend its manufacturing facilities by one more assembly line. A utility's decision of whether to invest in a new coal-fired power plant or an offshore wind park determines output for decades to come [16]. These decisions are critical in determining a firm's long-term competitive advantage. To refine the understanding of the mechanisms underlying strategic rigidity, this paper builds on the insights from the organisational theory and strategic management literature, particularly the idea that routines are costly and difficult to change once they are institutionalised. This paper explains this concept by outlining the cases of Iberdrola S.A., the world's largest RE developer and Spain's largest electric utility firm [17], and Enel S.p.A., Italy's largest electric utility firm and Europe's second-largest electric utility in terms of installed capacity. The case of Iberdrola illustrates the firm's core competence in the wind energy sector, which imparts competitive advantage in the RE market. lberdrola's expertise, know-how and superior capability in a more mature technology arrangement (wind energy) has made it strategically rigid in terms of adopting an innovative technology. i.e., concentrated solar power. Additionally. Enel's diversified renewable energy portfolio is embedded in the firm's mergers and acquisition decisions (Fig. 6). 
Table 1

Summary of referenees from different domains on organizational adoption of an innovative technology [18,19].

\begin{tabular}{|c|c|c|c|}
\hline Reference & Field & Context & Main findings and conclusions \\
\hline $\begin{array}{l}\text { Christensen } \\
\text { (1997) }\end{array}$ & $\begin{array}{l}\text { Technology strategy } \\
\text { organizational theory }\end{array}$ & $\begin{array}{l}\text { Response to disruptive technologies in the disk } \\
\text { drive industry }\end{array}$ & $\begin{array}{l}\text { Firms that have a competence in a given industry's dominant design and } \\
\text { vested interests in mainstream customers unable to take advantage of the } \\
\text { potential of disruptive technologies. }\end{array}$ \\
\hline $\begin{array}{l}\text { Christensen } \\
\text { and Bower } \\
(1996)\end{array}$ & Technology strategy & $\begin{array}{l}\text { Customer power and the failure of leading firms } \\
\text { world disk drive industry }\end{array}$ & $\begin{array}{l}\text { Established firms led the industry in the development of all types of } \\
\text { technologies when the technologies addressed existing customers' needs }\end{array}$ \\
\hline $\begin{array}{l}\text { Leonard-Barton } \\
(1992)\end{array}$ & Technology strategy & $\begin{array}{l}\text { New product and process development projects } \\
\text { in five firms: automobile, steel, chemicals and } \\
\text { electronics }\end{array}$ & $\begin{array}{l}\text { The core capabilities of a firm have a down side "core rigidities" that } \\
\text { inhibit innovation in organizations }\end{array}$ \\
\hline $\begin{array}{l}\text { Tushman and } \\
\text { Anderson } \\
\text { (1986) }\end{array}$ & Technology strategy & $\begin{array}{l}\text { Organizational responses to technological } \\
\text { discontinuities in the environment }\end{array}$ & $\begin{array}{l}\text { Discontinuities in the environment can be either competence enhancing or } \\
\text { competence destroying. }\end{array}$ \\
\hline $\begin{array}{l}\text { Karshenas and } \\
\text { Stoneman } \\
\text { (1993) }\end{array}$ & Economics & $\begin{array}{l}\text { Adoption of } \mathrm{CNC} \text { machines in the UK engineering } \\
\text { industry }\end{array}$ & $\begin{array}{l}\text { Supports rank and endogenous learning effects. Factors affecting the } \\
\text { diffusion include firm size, industry growth rates and cost of technology }\end{array}$ \\
\hline $\begin{array}{l}\text { Zmud and } \\
\text { Apple (1992) }\end{array}$ & Information systems & Scanners by supermarkets survey & Early adoption explained by chain size. \\
\hline $\begin{array}{l}\text { Woiceshyn and } \\
\text { Daellenbach } \\
\text { (2005) }\end{array}$ & $\begin{array}{l}\text { Industrial } \\
\text { organization, } \\
\text { strategic } \\
\text { management }\end{array}$ & Oil firms & $\begin{array}{l}\text { Adoption process explained by integrative capability developed through a } \\
\text { dynamic interplay of adoption process and knowledge systems. }\end{array}$ \\
\hline
\end{tabular}

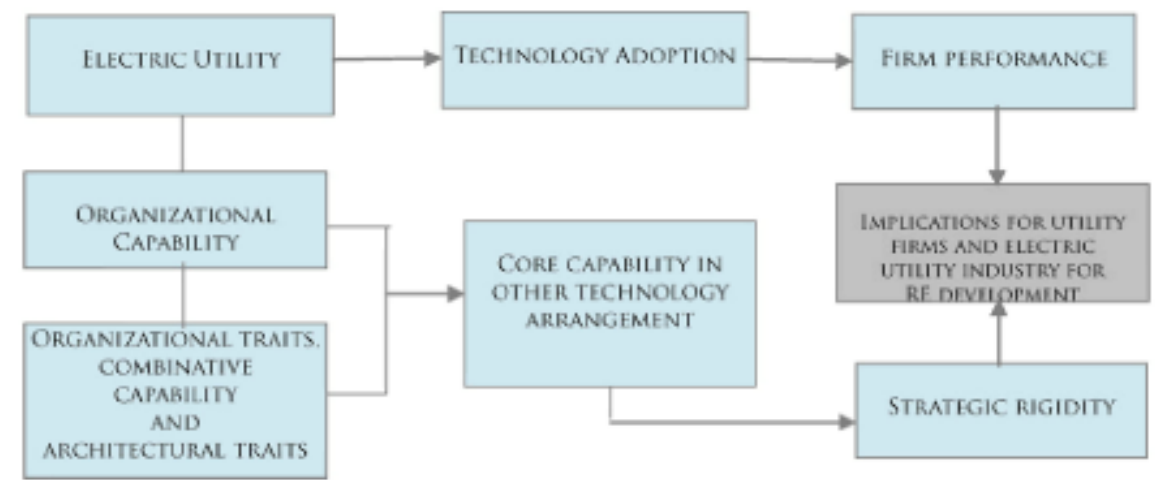

Fig. 1. Research framework for determining strategic rigidity in terms of technology adoption among electric utilities.

\section{Strategic rigidity and firm performance heterogeneity: frame of reference}

In the face of increased competition, unstable regulatory frameworks and rapid technological changes, sustainable competitive advantage is of profound importance to utility firms. These factors can undermine the longevity of a firm's competitive advantage. For example, dynamic and aggressive rivals can erode the market share of industry leaders, eventually leading to their dethronement [20]. Wiggins and Ruefli [21| understand that prior research identifying firms with sustained competitive advantage can be achieved as a series of temporary advantages over time. It is possible that these temporary advantages are a result of decisions made by the firm that may ultimately make the firm capable of maintaining it's competitive advantage. In the case of a utility firm, achieving competitive advantage requires managers to understand the bases of competitive advantage as well as the factors that lead to dynamic changes in these bases that allow them to concatenate a series of temporary advantages [22]. This series of competitive advantages or disadvantages relies on the strategic choices and decisions that a firm makes: for example, a decision regarding a merger or an acquisition of another utility firm or the adoption of an innovative technology. For instance, the Iberdrola S.A. acquisition of Scottish Power Plc. in 2007 can be categorised as a strategic choice to gain sustained competitive advantage (Fig. 2) Table 2

In theory, strategic choices are characterised by unique, novel, ambiguous and complex decision contexts; they require resource commitment (or the decision not to commit), and they are not easily reversible [23-25]. However, the very routines that create competitive advantage in firms are a liability, as they can become 'core rigidities,' or sources of competitive disadvantage, when firms confront environmental change. Given that the RE domain is constantly evolving, it is essential to document and examine firms that hold a certain level of expertise in mature technologies and that may become strategically rigid, thereby undermining the adoption of new technologies.

In responding to various environmental and market changes, technological innovation or the adoption of new technologies becomes the focal point for tension between innovation and the status quo microcosms of the paradoxical organisational struggle to maintain, yet also renew or replace, core capabilities [10]. The idea of capabilities has been discussed at length within the strategy literature, and its significance has been discussed for 


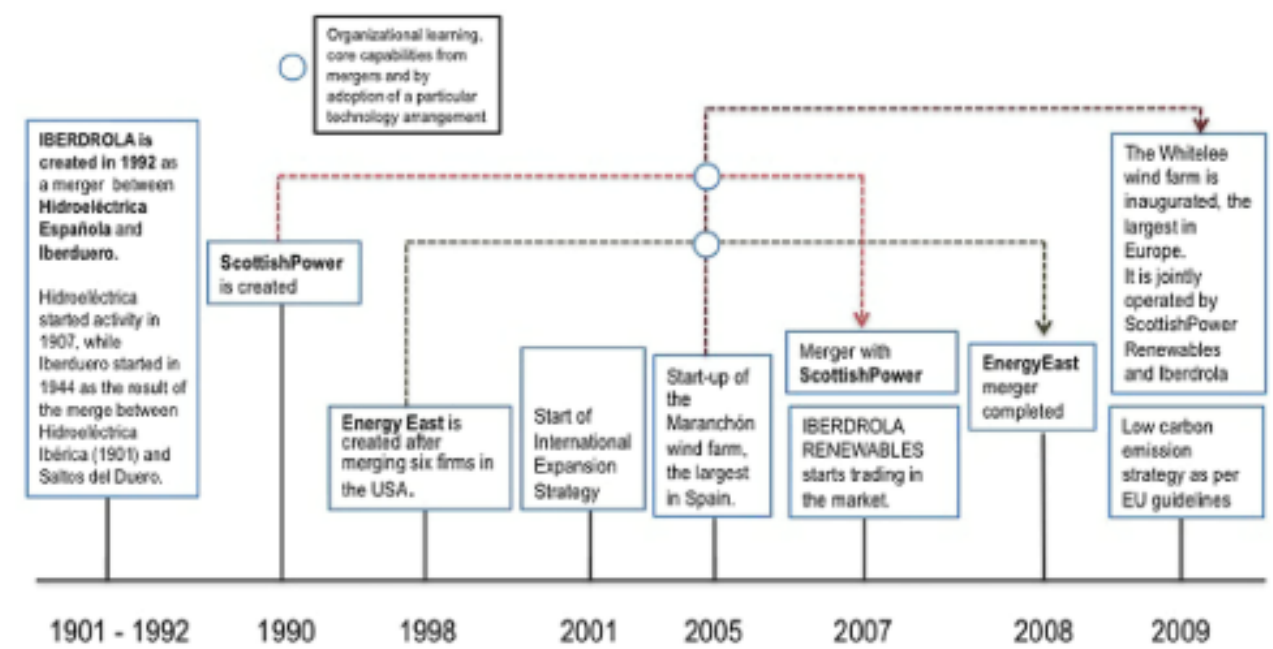

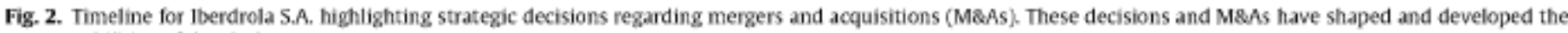
core capabilities of Iberdrola S.A.

Table 2

Road map for CSP policy making in Europe source:[46].

\begin{tabular}{|c|c|}
\hline Year & Possible outcome/enabling area activity \\
\hline $\begin{array}{l}\text { End of } 2010 \text { (Government } \\
\text { policy) }\end{array}$ & $\begin{array}{l}\text { The need for additional specific installation targets for solar energy (PV and CSP) in the EU is considered that will enable these } \\
\text { technologies to "catch up" with other, more mature renewable energy forms. }\end{array}$ \\
\hline \multirow[t]{3}{*}{$\begin{array}{l}2030 \text { (Investment and } \\
\text { financial policy) }\end{array}$} & $\begin{array}{l}\text { Renewable energy is viewed as a mainstream investment for the investor community. Risk mitigation mechanisms have been } \\
\text { successful and are gradually phased out. }\end{array}$ \\
\hline & $\begin{array}{l}\text { Utilities are now financing a larger proportion of renewable energy projects. End users are heavily imvolved in renewable energy } \\
\text { projects. }\end{array}$ \\
\hline & $\begin{array}{l}\text { CSP is cost competitive. Subsidies may start to be phased out for CSP and other established technology components and redirected into } \\
\text { strategic R\&D activities. }\end{array}$ \\
\hline $\begin{array}{l}2040 \text { (Infrastructure and } \\
\text { planning) }\end{array}$ & $\begin{array}{l}\text { CSP with storage and other renewable energy now provide the vast majority of total electricity generation across the EU. Newly } \\
\text { constructed generation capacity continues to replace ageing infrastructure until } 2050 \text {. }\end{array}$ \\
\hline $\begin{array}{l}2050 \text { (Infrastructure and } \\
\text { planning] }\end{array}$ & $\begin{array}{l}\text { Strong supply chains have been developed to support the industry, allowing for infrastructure plans to account for a supply of } 100 \% \\
\text { renewable electricity. }\end{array}$ \\
\hline
\end{tabular}

decades. Such notions have been stimulated by research, including Rumelt's [26] study, which found that of nine diversification strategies, the two that were formulated based on existing firm skills or capabilities were associated with the highest performance. Moreover, industry-specific capabilities increase the likelihood of a firm exploiting new technologies within the industry [27]. Prior literature supports the idea that effective competition is based on incremental innovation that exploits developed capabilities [28,29]. However, Lieberman and Montgomery [30] argue that institutionalised capabilities can lead to "incumbent inertia' in times of environmental change and that technological discontinuities can enhance or end existing competencies [31]. This series of studies forms the theoretical underpinnings of this paper, as we illustrate by studying the cases of Iberdrola and Enel.

\section{Branching, innovation and policy implications}

In this section, the paper extends the notion of sustaining competitive advantage by adopting new or novel technologies. Entry into new niches corresponds to the expansion of a firm's technological capabilities to drive innovation within and across technological domains. Prior research suggests that firms tend to maintain their competitive advantage by branching into new domains by recombining new with old knowledge/capabilities. This paper agrees with the considerable literature that branching into new technology domains increases the stock of opportunities that a firm may access $[32,33]$.
Furthermore, the knowledge that the firm acquires in the new domain can be recombined with its existing knowledge to introduce heterogeneity that facilitates problem solving $[34,35]$. Because older firms are more likely to have accumulated experience and slack resources [36], it is expected that they stand to benefit more from branching into new niches than younger firms if the incumbent firms can combine the process of branching with their core capabilities and accumulated knowledge.

To substantiate the theoretical notions, the following section explores the cases of Iberdrola S.A. and Enel S.p.A.

\section{Case study: Iberdrola S.A.}

In this section, the paper considers Iberdrola, the world's largest RE developer and Spain's largest utility firm. Iberdrola S.A. generates, distributes, trades, and markets electricity in the United Kingdom, United States, Spain, Portugal and Latin America. It specialises in clean energy, particularly wind power, and primarily operates in energy and utilities sector through three main business segments: regulated, liberalised and renewable energy. The regulated branch consists of energy transmission and distribution services, the liberalised energy division involves the production and sale of electricity and the renewable energy segment focuses on energy production. As of FY2011, the total installed capacity of Iberdrola was $46,026 \mathrm{MW}$ (MW). of which $58 \%$ was emission free. Fig. 3 highlights the core capability of Iberdrola in the wind energy sector, accounting for $97 \%$ of Iberdrola's renewable energy development [37]. 


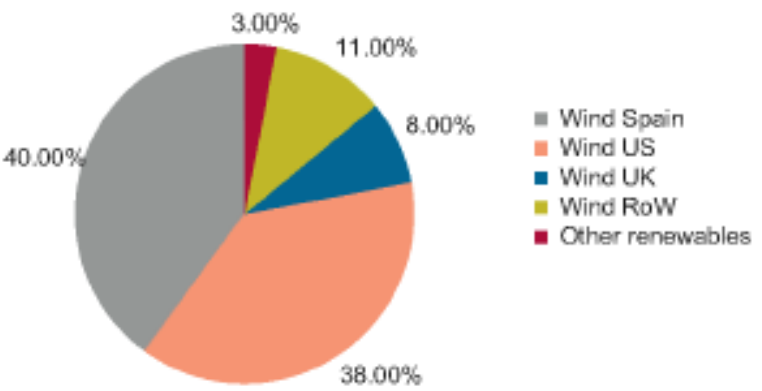

Fig. 3. Iberdrola's renewable energy production by region. Wind energy comprises nearly $97 \%$ of Iberdrola's total RE production. Source: Iberdrola S.A. [45].

\subsection{Mergers and acquisitions at Iberdrola S.A.}

This case illustrates the previous findings discussed in this paper and emphasises the possible implications of strategic rigidity in terms of new technology adoption for firm performance. Utility firms are becoming more engaged in RE development than ever before, and the continuation of this trend is seen as a possible future scenario. Firms' engagement in RE development is driven by a mix of regulatory incentives, the need for a hedge against potential carbon regulation and rising fossil fuel prices and the need for both base-load and peaking power capacity with short installation timelines [38].

The next section presents the current status of and future prospects for concentrated solar power technologies.

\subsection{Concentrated solar power technologies: status and future prospects}

Concentrated solar power (CSP) makes use of reflectors to focus sunlight on a small area to power a thermal electric plant. There are several technological variants, including fields of mirrors focusing sunlight on a tower, troughs of mirrors focusing sunlight on pipes and parabolic dishes focusing sunlight on their apex [39].

\subsection{Tïmeline for concentrated solar power technology}

During the 1980 s and early 1990s, nine concentrating solar power plants were constructed in California's Mojave Desert with a total capacity of $330 \mathrm{MW}$. During the subsequent years no new plants were built due to the weakening of the United States' federal support for renewables and dropping energy prices. An 11-MW plant in Spain - the first in Europe - became operational in March 2007. With more than $200 \mathrm{GW}$ of resource potential in the American southwest and thousands more throughout the world, CSP offers a rapidly scalable means of low-carbon electricity generation. Globally, there are more than 45 new CSP projects under development. These projects are scheduled to generate $5000 \mathrm{MW}$ in North America, $2500 \mathrm{MW}$ in Europe, more than $500 \mathrm{MW}$ in North Africa and $2400 \mathrm{MW}$ elsewhere [39,40]. Concentrated solar thermal generation is highly predictable and can be coupled with thermal storage or hybridisation (using gas or biomass), enabling stable electricity networks.

For the electric utility industry, CSP is increasingly valued as a hedge against carbon pricing and as a source of peaking or baseload-generating capacity (when paired with thermal storage or natural gas generation). CSP technologies promise a competitive value proposition, as CSP is not intermitted and can be delivered to the grid even when there is no solar radiation by using thermal storage or hybrid systems. This characteristic makes CSP more flexible than renewable technologies of an intermitted nature and

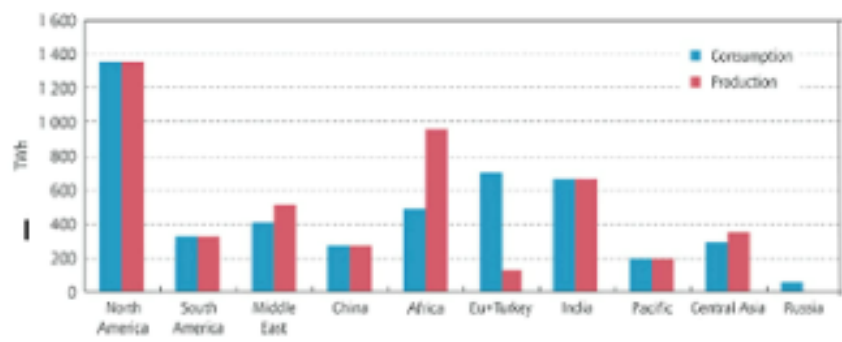

Fig. 4. Growth of CSP production by region by 2030 (TWh/y) [47].

thus contributes to enhanced operator management of the power system according to demand. CSP can facilitate integration of other technologies into the grid, such as photovoltaic or wind power. CSP avoids the need for fossil fuel backup because it can be easily hybridised with other forms of RE, such as biomass, or fossil fuels such as natural gas, thereby increasing the overall efficiency and reliability of power generation [41].

The table below depicts a possible road map for CSP development in Europe.

\subsection{Core capabilities, strategic rigidity and competitive advantage}

Iberdrola's leadership in RE is mainly based on wind energy, with a total installed capacity of $13.45 \mathrm{GW}$. Wind energy can be characterised as Iberdrola's core competence, which leads to the firm's competitive advantage (Fig. 2). To sustain this competitive advantage, it is essential for lberdrola to integrate multiple new technology streams with mature technologies to further develop its core competencies. Iberdrola has been critical of CSP technologies' potential and thus reluctant to adopt and integrate these technologies [42]. However, there is substantial evidence of the positive implications of CSP and the potential it holds for clean energy production (Fig. 4). Moreover, the CSP industry is scaling rapidly, with $1.2 \mathrm{GW}$ under construction as of 2009 and another $13.9 \mathrm{GW}$ projected globally by the end of 2014 (Fig. 4) [43]. Iberdrola's reluctance to adopt new technologies may pose a threat to near-future RE deployment [44]. Fig. 4 indicates the possible growth potential of CSP in various regions worldwide.

\section{Case study: Enel S.p.A.}

Enel is Italy's largest power company and one of Europe's major listed utilities. Enel is active in the power and gas sectors. Currently, Enel has operations in 40 countries, with 97,000 MW of net installed capacity as of 2011 [48].

\subsection{Enel green power}

Enel Green Power S.p.A. is a subsidiary of Enel S.p.A.; it was formed in 2008 to represent the renewable energy business of its parent firm, Enel S.p.A. Enel Green Power has operations in more than 16 countries across Europe, North America and South America, and it generates energy principally from hydroelectricity, wind, solar power, geothermal electricity and biomass sources. It has an installed capacity of over 7,700 MW from a mix of sources, including wind, solar, hydroelectric, geothermal and biomass [60]. Enel Green Power subsidiaries include Enel Green Power International B.V., Enel.si Srl, Enel Green Power Portoscuso Srl, Enel Green Power North America Inc., Enel Green Power Latin America B.V., Enel Green Power Bulgaria EAD, Enel Green Power Romania Srl, International Wind Parks of Thrace SA and Blue Energy Srl. Enel Green Power has a diversified renewable energy portfolio that is reflected in the M\&As of its parent firm. More recently, Enel Green Power undertook the first hybrid 
renewable energy project in the world that combines the continuous generation capacity of binary-cycle, medium-enthalpy geothermal power with the peak capacity of solar power Fig. 5.

\subsection{Mergers and acquisitions with technology adoption behaviour at Enel S.p.A}

Enel through its subsidiary Enel Green Power has been involved in a number of mergers and acquisitions that have attributed to the technology adoption behaviour. This has been considerably different from Iberdrola M\&A's decisions, as Enel has been focussing on a diverse technology arrangement for the adoption of renewable energy technologies. Some of the key decision are highlighted in Fig. 6. Emphasizing further on the diverse renewable technology adoption behaviour, in 2011, Enel Green Power started operations at the Caney River wind plant in Kansas US, with an installed capacity of more than $200 \mathrm{MW}$, and started construction of the 150 MW Rocky Ridge wind farm in Oklahoma. Further it acquired a $24 \mathrm{MW}$ photovoltaic plant supplementing the $33 \mathrm{MW}$ Stillwater geothermal plant. This has been the first renewable energy project that brings together the generation capacity of a binary cycle geothermal plant with the peak capacity of solar power. This resulted in the total installed capacity in North America to 1,000 MW.

Significantly, Enel is working towards the initiation of an ecosystem of diverse technologies, both mature and new, and for this purpose Enel Green Power has introduced an integrated

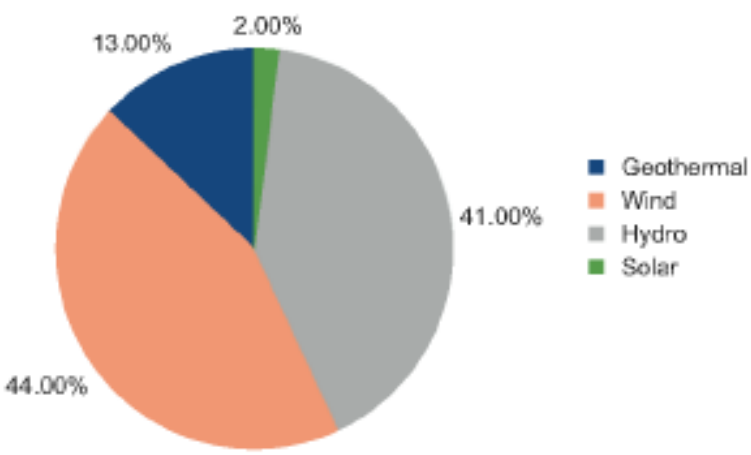

Fig. 5. Enel renewable energy portfolio. Source: [49]. program of activities in the entire photovoltaic area. This has been accomplished with the manufacture of high-efficiency photovoltaic panels, with the inauguration of the 3Sun factory (a joint venture with Sharp, Japanese based electronics firm and STMicroelectronics, French-Italian based electronics firm), the development of solar power projects through the fully- functioning ESSE (a joint venture with Sharp), and new products in the retail segment $[49,66]$.

\section{Energy policy, economies of scale and renewable energy technologies}

Many economies have adopted measures towards unbundling public utilities into separate operations based on regulatory reforms in the energy sector. The traditional models based on vertical integration in single sectors are often excluded. Especially in the electricity sector, vertically integrated firms are generally required to unbundle the production, transmission and distribution functions. For instance, directive 2003/54/EC of the European Parliament and the EU Council of 26 June 2003 requires a legal and functional unbundling of the utilities operating in a single sector [51]. Despite the accepted wisdom regarding the advantages of RE, the acceptance of some new renewable technologies remains inadequate. The applied policies for the diffusion of these technologies have mainly focused on two critical poles: technology development and investment in production facilities. The dominant approach focuses on the substitution of individual technologies and ignores the interaction of technology diffusion, system restructuring and technology development [52].

Moreover, the discourse on energy policy has been based on the assumption that the focus should be on the energy or electricity system as a whole; policy initiatives with respect to deregulation, investment and environmental impact must be considered as a part of this system, from generation to transmission to distribution and finally to consumption. However, a prospect that has eluded policy makers for many years is the mismatch in demand and growth for some RE technologies, as in the case of solar thermal installations. As new RE technologies translate into new services that can be commercialised, the focus for firms within the industry will shift from R\&D to the deployment of these new technologies. As a result, cumulative

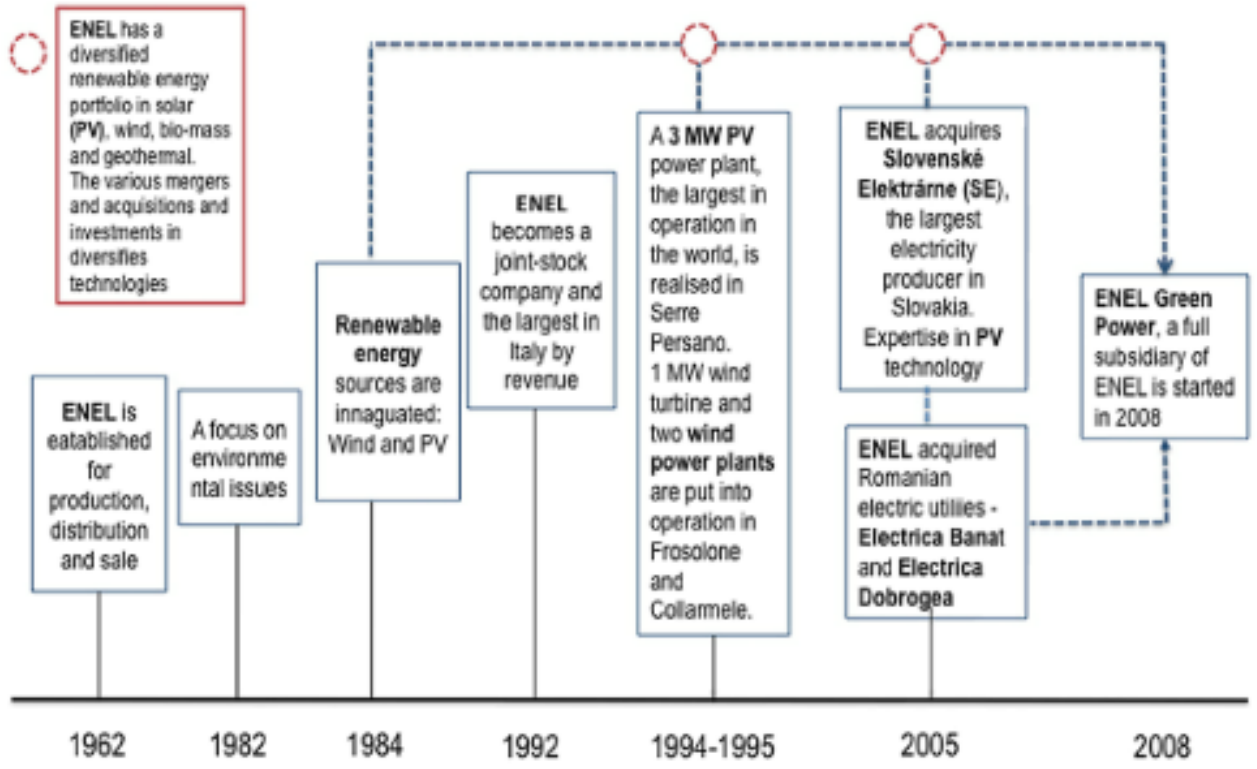

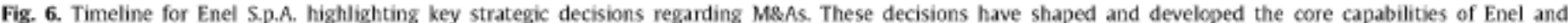
determined its diversified renewable energy portfolio. Source: [49,50]. 
experience resulting simply from deployment activity may bring about significant cost reductions. Thus, prior capabilities among mature technologies may yield a variety of process improvements, including cost reduction. Learning curves have been extensively used to describe this phenomenon of "learning by doing" for the deployment of new energy technologies $[53,54]$.

Further, scholars have suggested that new knowledge is created by unique recombination of existing knowledge repositories [55-57,62]. Entry into new niches corresponds with the expansion of a firm's technological capabilities to drive innovation within and across these technological domains. Moreover, Kotha et al. [58] suggest that when a firm branches out into niche or new technological domains, it can combine new knowledge with its existing knowledge to yield radical innovation. While this transformation may have positive implications, entering multiple new technological niches may prove to be counterproductive. As a result, it becomes difficult for a firm to absorb knowledge over multiple domains [64].

\section{Network effects}

Furthermore, there may be 'network externalities,' which are sometimes called 'network effects' or 'peer effects,' in the adoption of distributed generation renewables. Network externalities occur when the utility an individual user derives from a product increases with the number of other users of that product. The externality stems from the spillover from one user's consumption of the product has on others, so that the magnitude of the externality is a function of the total number of adoptions of the product [65]. This term refers to the process whereby others' decision to adopt affects the utility an individual receives from adopting (and thus the probability of adoption). Therefore, a critical mass of consumers must adopt the technology for it to become widespread. Bollinger and Gillingham [59] find strong empirical evidence for such effects in the adoption of solar photovoltaic panels in California. Of course, network effects may not always constitute a market failure, as in many cases, there may be compensation for the spill over (e.g., neighbours may help each other in various ways and thereby potentially internalise the externality). In the context of renewable energy, network externalities may play a role in the adoption of distributed generation $[61,63]$.

\section{Discussion and conclusions}

This paper has examined a firm-level perspective on technology adoption behaviours among electric utilities. Substantively, building on organisational theory and strategic management literature, this paper makes the following contributions. Firstly, a comprehensive review of literature on technology adoption behaviours based on organisational learning and core capabilities is provided. At the firm level, core capabilities are evolving. A firm's survival depends on its successful adoption of new technologies and management of that evolution. Such decisions can be a source of conflict between the need for new technologies and the retention of mature technologies' important capabilities. Secondly, the cases of Iberdrola and Enel are discussed to highlight incumbent inertia with respect to technology adoption decisions regarding a novel technology that may yield competitive advantage within the firm's industry. In conclusion, a firm's core capabilities are continually evolving, and the firm's survival depends upon its successful management of that evolution. A firm's adoption of new technologies and processes is a visible factor that may lead to rigidity and potential conflict between the need for new technology adoption and for retention of important capabilities within existing technologies.

\section{References}

[1] Barney JB. Resource-based theories of competitive advantage: a ten-year retrospective on the resource-based view. Journal of Management 2001;27 643-50.

[2] Wernefelt B. A resource-based view of the firm. Strategic Management Joumal 1984;5:171-80.

[3] Richard D. Weick KE. Toward a model of organizations as interpretation systems. Academy of Management Review 1984:9:284-95.

4] Miles RE, Snow CC. Organizational strategy, structure and process. New York McGraw- Hill: 1978.

[5] Selznick P. Leadership in administration: a sociological interpretation. EvanSton IL Row: Peterson and Co; 1957.

[6] Learned EP, Christensen CR, Andrews K, Guth WD. Business policy: text and cases, II: Irwin: Homewood; 1969 ,

[7] Nelson RR, Winter SC. An evolutionary theory of economic change. Cambridge MA: Harvard University Press; 1982.

[8] Henderson $R$, Clark K. Architectural innovation: the reconfiguration of existing product technologies and the falure of established firms. Administrative Science Quarterly 1990;35:9-30.

[9] Prahalad CV, Hamel C. The core competence of the corporation. Harvard Business Review 1990;68:79-91.

[10] Leonard-Barton D. Core capabilities and core rigidness: a paradox in managing new product development. Strategic Management Journal 1992;13: $111-25$.

[11] Kogut B, Zander U, Knowledge of the firm, combinative capabilities, and the replication of technology. Organization Science 1992;3:383-97.

[12] Henderson R, Cockburn L. Measuring competence? exploring firm effects in pharmaceutical research Strategic Management Joumal 1994:15:63-84.

[13] March JG. Exploration and exploitation in organizational learning. Organization Science 1991;2;71-87.

[14] Day CS. The capabilities of market-driven organizations. journal of Marketing 1994:58:37-52.

[15] Teece DJ, Pisano $C$, Shuen A Dynamic capabilities and strategic management. Strategic Management Joumal 1997;18:509-33.

[16] Wustenhagen R, Menichetti E Strategic choices for renewable energy investment: conceptual framework and opportunities for further research. Energy Policy 2012;40:1-10.

[17] mww-rechargenews,com See <http://www.rechargenews,com/business_area/ finance/article303237.ece) [accessed 28.05.12].

[18] Srinivasan R, Lilien GL, Rangaswamy A. Technological opportunism and radical technology adoption: an application to E-business. Journal of Marketing 2002:65:47-60.

[19] Woiceshyn J, Daellenbach U. Integrative capability and technology adoption: evidence from oil firms. Industrial and Corporate Change 2005;14(307):342

[20] Ferrier W, Smith KG. Grimm CM. The role of competitive action in marke share erosion and industry dethronement: a study of industry leaders and challengers. Academy of Management Joumal 1999;42:372-88.

[21] Wiggins RR, Ruefli TW. Schumpeter's ghost: is hyper competition making the best of times shorter? Strategic Management Journal 2005:26:887-911.

[22] Sirmon DG, Hitt M, Jean-Luc Arregle A, Campbell JT. The dynamic interplay of capability strengths and weaknesses: investigating the bases of temporary competitive advantage. Strategic Management Journal 2010:31:1386-409.

[23] Bansal P. Responsible strategic decision making. In: Proceedings of the sixteenth annual meeting of the international association for business and society, sonoma valley. California, USA; 2005.

[24] Eisenhardt KM, Zbaracki MJ. Strategic decision-making. Strategic Management Journal 1992;4:17-37.

[25] Mintzberg H, Raisinghani D, Theoret A. The structure of "unstructured" decision processes. Administrative Science Quarterly 1976:2:246-75.

[26] Rumelt RP. Stratezy, structure and economic performance. Boston, MA, USA: Harvard Business School Classics, Harvard Business School Press; 1974.

[27] Mitchell W. Whether and when? Probability and timing of incumbents' entry into emerging industrial subfields Administrative Science Quarterly $1989 ; 34$ 208-30.

[28] Hayes RH. Strategic planning-forward in reverse? Harvard Business Review 1985:111-9.

[29] Quinn JB. Strategies for change: logical incrementalism. IL. USA: Richard D Invin. Homewood; 1980.

[30] Lieberman M, Montgomery DB. First-mover advantages. Strategic Management Joumal 1988:9:41-58.

[31] Tushman ML. Anderson P. Technological discontinuities and organizational environments. Administrative Science Quarterly 1986;31:439-65.

[32] Fleming L. Recombinant uncertainty in technological search. Management Science 2001:47:117-32.

[33] Fleming L, Sorenson O. Science as a map in technological search. Strategic Management Joumal 2004;25:909-28.

[34] Amabile TM. A model of creativity and innovation in organizations. Research in Organizational Behavior 1988;10:123-67. 
[35 George G, Kotha R, Zheng Y. The puzzle of insular domains: a longitudinal study of knowledge structuration and innovation in biotechnology firms. Journal of Management Studies 2008;45:1448-74.

[36 Penrose E. The Theory of the growth of the firm. New York. USA: Oxford University Press; 1959 .

[37 Bloomberg: < http://www.bloomberg.eom/quote/IBE:SM/profile > [accessed 01.06.12).

[38 REN21. Renewables 2010 Global Status Report. REN21; 2010.

[39 Cavallaro F. Multi-criteria decision aid to assess concentrated solar thermal technologies. Renewable Energy 2009;34:1678-85.

[40 United Nations, The promise of solar energy: a low carbon energy strategy for the 21 st century; 2007

[41 Deloitte and Protermosolar, Macroeconomic impact of the Solar Thermal Electricity Industry in Spain, Madrid, Spain; 2011.

[42 CSPTODAY. Iberdrola: suddenly sour on solar thermal. Available from: <http://social.csptoday.com/technology/iberdrola-suddenly-sour-solar-ther mal> [accessed 01.01.12)

[43 Emerging Energy Research <http://www.renewableenergyworld.com/rea/ news/article/2009/05/global-concentrated-solar-power-industry-to-reach-25gw-by-2020>. [accessed 01.06.12).

[44 Renewable energy focus, concentrated solar thermal power (CSP) market could reach $24 \mathrm{GW}$ by 2020.2009.

[45 Iberdrola SA <http://www.iberdrola.es/webibd/corporativa/iberdrola7cam bioIdioma=ESWEBCONLINRENOVABLES>. [accessed 01.06.12).

[46 PricewaterhaouseCoopers, $100 \%$ renewable electricity: a roadmap to 2050 for Europe and North Africa; 2010.

[47 International Energy Agency (IEA), Technology roadmap: concentrating solar power, Paris, France; 2002.

[48 Financial Times < http://markets.ft.com/Research/Markets/Tearsheets/Busi ness-profile?s=ENEL:MIL> [accessed 23.07.12)

[49 Enel Green Power (EGP) <http://www.enelgreenpower.com/en-GB/com pany/> [accessed 23.07.12J.

[50 Enel A <http://www.enel.com/en-GB/group/about_us/history/> [accessed 25.07.12)

[51 Farsi M, Fetz A, Filippini M. Economies of scale and scope in the swiss multiutilities sector. CEPE Working Paper no. 59; 2007.
[52 Tsoutsos TD, Stamboulis AY. The sustainable diffusion of renewable energy technologies as an example of an innovation focussed policy. Technovation 2005;25:753-61.

[53. Wene C. Experience curves for technology policy. Paris: International Energy Agency. OECD; 2000

[54 McDonald A, Schrattenholzer L. Learning rates for energy technologies. Energy Policy 2001;29:255-61.

[55 Basalla G. The evolution of technology. Cambridge. MA. USA: Cambridge University Press; 1988.

[56 Henderson R, Cockburn I. Measuring competence? Exploring firm effects in pharmaceutical research Strategic Management Journal 1994;15:63-84.

[57 Schumpeter JA. Business cycles. New York, USA: McGraw-Hill; 1939.

[58 Kotha R, Zheng Y, George G. Entry into new niches: the effects of firm age and the expansion of technological capabilities on innovative output and impact. Strategic Management Journal 2011;32:1011-24.

[59 Bollinger B, Gillingham K. Peer effects in the diffusion of solar photovoltaic panels. Stanford University Working Paper; 2011.

[60 Renewable Energy Focus. Available from: <http://www.renewableenergyfo cus.com/view/22916/enel-green-power-installs-880-mw-of-wind-and-solarin-2011/> [accessed 15.01.13)

[61 Yu CS, Tao YH. Understanding business-level innovation technology adoption. Technovation 2009;29:92-109.

[62 Bocquet R, Brossard O, Sabatier M. Complementarities in organizational design and the diffusion of information technologies: an empirical analysis. Research Policy 2007;36:367-86.

663 Damanpour F, Gopalakrishnan S. Theories of organizational structure and innovation adoption: the role of environmental change. Journal of Engineering and Technology Management QETM) 1998;15:1-24.

[64 Cowan KR, Daim TU. Review of technology acquisition and adoption research in the energy sector. Technology in Society 2011;33(3):183-99.

[65 Gillingham K, Sweeney J. Market failure and the structure of externalities; 2010.

[66 Enel: <http://www.enel.com/en-GB/doc/report2011/report_and_financiaL statements_of_enel_spa_2011.pdf $>$ [accessed 15.01.13J. 